\title{
Tindak Tutur Direktif Guru Perempuan dalam Pembelajaran Bahasa Indonesia Kelas XI SMA
}

\author{
Oleh: \\ Iros Niya Wati; Nurlaksana Eko Rusminto; Bambang Riadi \\ Prodi Pendidikan Bahasa dan Sastra Indonesia \\ Fakultas Keguruan dan Ilmu Pendidikan Universitas Lampung \\ E-mail: irosniya29@gmail.com
}

\begin{abstract}
The purpose of this research is to describe the function and realization of directive speech of female teachers in Indonesian language learning class XI SMA Negeri 1 Seputih Mataram Lampung Tengah in academic year 2016/2017. This research was conducted through descriptive qualitative method. Sources of data in this research were taken from the speeches of female teachers in Indonesian language learning class XI through observation and documentation. The data were analyzed by using heuristic analysis technique. The result of the research shows that the directive speech of female teachers based on communicative function which is more dominant found is the imperative directive speech, while the directive speech of female teachers based on the realization which is more dominant found is direct speech.
\end{abstract}

\begin{abstract}
Abstrak. Tujuan penelitian ini untuk mendeskripsikan fungsi dan realisasi tindak tutur direktif guru perempuan dalam pembelajaran bahasa Indonesia kelas XI SMA Negeri 1 Seputih Mataram Kabupaten Lampung Tengah tahun pelajaran 2016/2017. Sejalan dengan tujuan penelitian, metode yang digunakan adalah deskriptif kualitatif. Sumber data dalam penelitian ini adalah tindak tutur guru perempuan pada saat pembelajaran bahasa Indonesia kelas XI. Kemudian, data dikumpulkan dengan teknik observasi, rekam dan catat. Teknik analisis data menggunakan analisis heuristik. Hasil penelitian menunjukkan bahwa tindak tutur direktif guru perempuan berdasarkan fungsi komunikatif yang lebih dominan ditemukan adalah tindak tutur direktif memerintah, sedangkan tindak tutur direktif guru perempuan berdasarkan realisasi tuturannya yang lebih dominan ditemukan adalah tindak tutur langsung.
\end{abstract}

Kata kunci: tindak tutur direktif, guru perempuan 
AKSARA Jurnal Bahasa dan Sastra

Vol. 18, No. 2, Hal. 100 - 112, Oktober 2017

http://jurnal.fkip.unila.ac.id/index.php/aksara

\section{PENDAHULUAN}

Komunikasi dapat dipandang sebagai gabungan atau kombinasi dari berbagai tindak, serangkaian unsur dengan maksud dan tujuan tertentu. Oleh karena itu, komunikasi bukan hanya suatu peristiwa belaka yang terjadi dengan sendirinya, tetapi komunikasi mempunyai fungsi, mengandung maksud dan tujuan tertentu yang dirancang untuk menghasilkan efek atau akibat pada lingkungan para penyimak dan pembicara. Komunikasi yang digunakan itu ialah tindak tutur direktif.

Tindak tutur direktif adalah ilokusi yang bertujuan untuk menghasilkan suatu efek atau akibat berupa tindakan yang dilakukan oleh mitra tutur sesuai apa yang disebutkan di dalam tuturannya (Searle dalam Rusminto, 2015: 69). Selain itu, tindak tutur direktif juga bisa mengekspresikan maksud penutur, seperti keinginan dan harapan sehingga tindak tutur atau sikap yang diekspresikan dapat dijadikan sebagai alasan untuk bertindak oleh mitra tutur (Ibrahim, 1993: 27). Tindak tutur direktif tersebut mengandung fungsi komunikatif, seperti meminta, menanya, memerintah, melarang, mengizinkan, dan menasihati Ibrahim (1992: 27-29).

Begitu juga dalam pembelajaran di kelas, tindak tutur yang digunakan oleh guru cukup bervariasi, namun pada kenyataan tindak tutur yang sering digunakan guru lebih didominasi oleh tindak tutur yang menuntut siswa melakukan suatu tindakan seperti yang dituturkan. Tindak tutur yang digunakan itu ialah tindak tutur direktif. Hal ini menguatkan apa yang dikemukakan Ibrahim (1993

: 212) bahwa dalam pembelajaran di kelas, guru memiliki lebih banyak power dan kontrol daripada siswa sehingga banyak tindak tutur kelas dikarakterisasi oleh dominasi guru. Oleh karena itu, dalam mewujudkan hal tersebut, guru harus memiliki kemampuan komunikasi dengan siswanya, seperti memilih tuturan yang tepat dalam bertindak tutur, baik secara langsung maupun tidak langsung.

Langsung maupun tidak langsungnya tuturan yang dipilih tersebut merupakan suatu kemampuan guru dalam mengungkapkan tuturan direktif. Dalam hal ini, tentunya guru pun harus pandai untuk menentukan tuturan yang dianggap tepat untuk mencapai tujuannya tersebut. Dikatakan demikian karena setiap siswa memiliki sifat dan karakter yang berbeda sehingga jika guru tidak selektif menentukan tuturan maka berdampak pada tujuan dan hubungan sosial dengan siswanya. Dalam proses pembelajaran di kelas, sebagai sarana komunikasi dan memelihara kerja sama, fungsi bahasa dapat diwujudkan dengan cara membangun interaksi gurusiswa yang harmonis dan senyaman mungkin. Hubungan yang harmonis memungkinkan terjadinya pemahaman yang komprehensif tentang ilmu yang sedang diajarkan oleh guru kepada siswa.

Seperti halnya guru perempuan pada saat mengajar di kelas. Perempuan lebih sering dan cenderung menggunakan gaya tutur kooperatif (Santoso, 2011: 2). Kooperatif 
artinya, bersifat kerja sama dan bersedia membantu (KBBI, 2008: 731). Selain itu, suara perempuan juga lebih lembut, dan hal ini juga sedikit banyak berkaitan dengan nilai sosial atau tata krama dan sopan santun (Sumarsono, 2014: 99-103). Oleh karena itu, perempuan cenderung memiliki sifat kerja sama, dan lebih lembut, baik dalam bertindak tutur, maupun dalam tingkah laku.

Berdasarkan uraian yang telah dikemukakan, perlu dilakukan penelitian tentang masalah bahasa perempuan khususnya yang beprofesi sebagai guru. Hal ini karena pada dasarnya peranan guru di kelas telah membentuk komunikasi bahasa yang tipikal dan teridentifikasi sebagai ciri khas tindak bahasa atau tindak tutur guru. Oleh karena itu, tindak tutur guru dalam kelas sangat berbeda dengan tindak tutur dalam peristiwa tutur di luar kelas. Beberapa hal yang menjadi ciri khas tuturan guru, umumnya cenderung ditandai dengan banyaknya tuturan yang menindakkan tindak tutur tertentu, misalnya menginformasikan, menjelaskan, memerintah, mendefinisikan , menanyakan, menarik perhatian, dan memotivasi. Berdasarkan karakteristik tersebut maka tindak tutur guru dalam kelas teridentifikasi memiliki ciri khas tersendiri. Tuturan tersebut merupakan ciri perwujudan dari tindak tutur direktif. Dengan demikian, penelitian ini berfokus pada tindak tutur direktif yang dilihat berdasarkan fungsi komunikatif dan realisasi tuturannya. Selain itu, diperlukan konteks situasi tutur untuk mempertimbangkan bentuk informasi saat tuturan itu berlangsung supaya analisis yang dilakukan bisa menjelaskan berbagai kemungkinan makna tindak tutur direktif.

Penulis memilih penelitian di SMA Negeri 1 Seputih Mataram J1. Merapi Pajar Mataram Kecamatan Seputih Mataram Kabupaten Lampung Tengah karena penulis bermaksud mengetahui secara langsung bagaimana penggunaan tindak tutur direktif guru perempuan yang mengajar bahasa Indonesia kelas XI di sekolah tersebut.

Sesungguhnya, kajian tindak tutur sudah banyak dilakukan. Kemudian, pada penelitian ini, peneliti mengikuti jejak penelitian sebelumnya yang dilakukan oleh Sari yang meneliti tentang "Tindak Ilokusi Guru Bahasa Indonesia dalam Kegiatan Pembelajaran SMP Muhammadiyah 1 Pekalongan Lampung Timur tahun pelajaran 2009/2010. Adapun kesamaan penelitian Sari dengan penelitian saat ini adalah meneliti tindak tutur direktif. Kemudian, perbedaannya terletak pada kajian dan teori. Sari meneliti juga tindak tutur asertif sedangkan pada penelitian ini hanya tindak tutur direktif guru perempuan. Begitu juga dengan teori yang digunakan Sari dalam penelitiannya menggunakan teori Searle, sedangkan penelitian ini menggunakan teori Ibrahim. Dengan demikian, penelitian ini berjudul "Tindak Tutur Direktif Guru Perempuan dalam Pembelajaran Bahasa Indonesia Kelas XI SMA Negeri 1 Seputih Mataram Kabupaten Lampung Tengah Tahun Pelajaran 2016/2017". 


\section{METODE PENELITIAN}

Penelitian ini menggunakan metode deskriptif kualitatif. Kemudian, subjek dalam penelitian ini adalah guru perempuan yang mengampu mata pelajaran Bahasa Indonesia di kelas XI bernama Yayun Riwinasti, S.Pd. Selanjutnya, sumber data dalam penelitian ini berupa tindak tutur guru perempuan yang mengajar bahasa Indonesia kelas XI dan data penelitian ini berupa tindak tutur direktif dan realisasi tuturannya yang digunakan guru perempuan dalam pembelajaran bahasa Indonesia kelas XI SMA Negeri 1 Seputih Mataram Kabupaten Lampung Tengah tahun pelajaran 2016/2017.

Kaitannya dalam pemerolehan data, data diperoleh dengan teknik observasi nonpartisipasi sehingga peneliti hanya menyimak tanpa melibatkan diri selama proses pembelajaran di kelas. Kemudian, peneliti juga menggunakan alat bantu, yakni hendycam untuk merekam tuturan. Selain rekaman, peneliti juga menggunakan catatan lapangan, yakni catatan deskriptif dan reflektif. Catatan deskriptif berupa catatan tentang semua fungsi komunikatif tindak tutur direktif dan realisasi tuturannya yang melihat pada konteks tuturan. Kemudian, catatan reflektif digunakan untuk interpretasi atau penafsiran peneliti terhadap tindak tutur direktif yang digunakan oleh guru perempuan di kelas. Pengumpulan data berakhir setelah data yang terkumpul cukup untuk diproses dan dianalisis.

Data yang terkumpul dianalisis dengan teknik analisis heuristik. Dengan merujuk pada teori tersebut maka data-data penelitian yang diperoleh akan dianalisis menggunakan langkah-langkah sebagai berikut.

1. Menyimak dan mencatat secara langsung data alamiah saat pembelajaran Bahasa Indonesia di kelas XI SMA Negeri 1 Seputih Mataram kabupaten Lampung Tengah tahun pelajaran 2016/2017.

2. Data yang didapat langsung dianalisis dengan menggunakan catatan deskriptif dan reflektif juga menggunakan analisis heuristik.

3. Mengidentifikasi data yang mengandung tindak tutur direktif.

4. Mengklasifikasikan data tindak tutur direktif berdasarkan fungsi komunikatif tindak tutur direktif dan realisasi tuturannya yang melihat pada konteks tuturan.

5. Memeriksa atau mengecek kembali data yang ada.

6. Menarik simpulan akhir.

\section{HASIL PENELITIAN DAN PEMBAHASAN}

Hasil penelitian dan pembahasannya dipaparkan berdasarkan pada urutan permasalahan dan tujuan penelitian berikut ini. 


\section{Fungsi Komunikatif Tindak Tutur Direktif}

Berdasarkan hasil penelitian ini menunjukkan bahwa guru perempuan menggunakan tindak tutur direktif dalam pembelajaran di kelas terdiri atas meminta, menanya, memerintah, melarang, mengizinkan, dan menasihati. Proporsi penggunaannya dibahas sebagai berikut.

\section{a. Tindak Tutur Direktif Meminta}

Tindak tutur direktif meminta adalah tindak tutur yang digunakan penutur untuk mengekspresikan keinginan agar mitra tutur melakukan tindakan sesuai yang dimaksudkan oleh penutur yang ditandai dengan kata minta, tolong, mohon, seandainya, semoga, dan partikel -lah. Berikut ini disajikan data tindak tutur direktif meminta beserta pembahasannya.

Guru : "Ibu minta untuk setiap baik itu keterangan maupun dialog nanti diberikan penomoran." (029/Mt-07/L)

Siswa: (Menjawab serentak) "Iya, Bu."

\section{Konteks}

Tuturan tersebut merupakan tindak tutur direktif yang mengandung fungsi komunikatif meminta. Fungsi meminta pada tuturan tersebut dapat ditandai dengan adanya tuturan kata "minta". Pada tuturan tersebut guru menginginkan agar para siswa memberikan penomoran pada setiap keterangan maupun dialog.

\section{b. Tindak Tutur Direktif Menanya}

Tindak tutur direktif yang mengandung fungsi komunikatif menanya adalah tindak tutur yang digunakan oleh penutur untuk meminta kepada mitra tutur agar memberikan informasi atau penjelasan yang ditandai dengan tanda (?) dan tuturan kata apa, siapa, dimana, kapan, mengapa, bagaimana, ya, dan partikel -kah. Berikut ini disajikan data tindak tutur direktif menanya beserta pembahasannya.

Ketika Guru sedang menjelaskan, datang siswa yang bernama Jodi dan langsung menyerahkan surat kepada guru).

Siswa : (Jodi menghampiri guru dan memberikan surat izin perlombaan)

Guru : "Mau lomba dimana?" (163/Ty-39/L)

Siswa : (Jodi) "Di STM, Bu."

Guru : "Oh, ya. Ibu doakan semoga menang."

Siswa : (Menjawab serentak) "Amin."

\section{Konteks}

Pada data di atas, penutur (guru) menggunakan tindak tutur direktif yang mengandung fungsi komunikatif menanya. Pada tuturan "Mau lomba dimana? "merupakan tuturan menanya pada mitra tutur (siswa yang bernama Jodi) mengenai tempat pelaksanaan perlombaan tersebut. Tindak tutur menanya ini dapat diketahui dengan adanya penanda lingual "dimana” yang terdapat pada tuturan. 


\section{c. Tindak Tutur Direktif Memerintah}

Tindak tutur direktif yang mengandung fungsi komunikatif memerintah adalah tindak tutur yang digunakan oleh penutur untuk mengekspresikan maksud agar mitra tutur melakukan tindakan yang sesuai dengan keinginan penutur yang ditandai dengan tanda (!) dan tuturan kata Ayo, coba, dan partikel -lah. Berikut ini disajikan data tindak tutur direktif memerintah beserta pembahasannya.

Guru : "Coba perhatikan sebentar ya, waktunya sudah habis." (047/Pr-16/L) (Sambil menunjuk jam dinding).

Siswa : (Langsung memerhatikan) "Iya, Bu."

\section{Konteks}

Tuturan tersebut merupakan tindak tutur direktif yang mengandung fungsi komunikatif memerintah yang ditandai dengan adanya penanda lingual "Coba"yang menghendaki agar para siswa terlebih dahulu memerhatikan.

\section{d. Tindak Tutur Direktif Melarang}

Tindak tutur direktif yang mengandung fungsi komunikatif melarang adalah tindak tutur yang digunakan penutur untuk memberikan larangan atau membatasi melakukan suatu tindakan yang ditandai dengan verba "jangan", dan "tidak." Berikut ini disajikan data tindak tutur direktif melarang beserta pembahasannya.

Guru : "Kalau satu temannya sudah selesai, langsung bergantian dengan temannya."

Siswa : "Sudah sepuluh menit."

Guru : "Jangan diganggu." (96/Lr-06/L)

Siswa : (Langsung terdiam dan kembali menghitung kecepatan membaca Temannya)

\section{Konteks}

Pada tuturan "Jangan diganggu." Merupakan suatu larangan atas tuturan mitra tutur yang mengatakan bahwa waktu membaca temannya telah sepuluh menit. Dengan demikian, guru pun melarang siswa tersebut agar tidak mengganggu temannya yang sedang membaca. Tuturan melarang tersebut juga dapat diketahui dengan melihat penanda lingual “jangan"yang terdapat pada tuturan.

\section{e. Tindak Tutur Direktif Mengizinkan}

Tindak tutur direktif mengizinkan adalah tindak tutur yang digunakan oleh penutur untuk memberikan kehendak kepada mitra tutur melakukan suatu perbuatan yang dapat ditandai dengan penanda verba "silakan, boleh, dan tidak harus". Berikut ini disajikan data tindak tutur direktif mengizinkan beserta pembahasannya.

Guru : "Nah, siapa ini yang akan menanggapi tokoh kejadian utama ini?"

Siswa : (Serentak menjawab) "Robet."

Guru : "Mau bertemu dengan Robet, ya boleh.” (033/Iz-04/L)

(Sambil menuliskan nama Robet di kolom para tokoh) 


\section{Konteks}

Tuturan tersebut merupakan tindak tutur direktif yang mengandung fungsi komunikatif mengizinkan. Pada tuturan tersebut, guru telah mengabulkan keinginan para siswa jika Robet yang akan menanggapi tokoh (Angga) pada kejadian utama dalam pementasan drama yang ditandai dengan tuturan kata " $y a$ ", dan "boleh" yang terdapat pada tuturan.

\section{f. Tindak Tutur Direktif Menasihati}

Tindak menasihati adalah tindak tutur yang digunakan penutur untuk mengekspresikan suatu anjuran (petunjuk, petuah, teguruan, peringatan) yang dapat ditandai dengan penanda verba "agar, sebaiknya, seharusnya, supaya, pastikan walaupun, dan hendaknya. Berikut ini disajikan data tindak tutur direktif menasihati beserta pembahasannya.

Siswa : "Bu, bukunya dikumpul."

Guru : "Iya bukunya dikumpul. Untuk notulennya belum selesai ibu koreksiya."

Siswa : "Tapi bukunya jadi satu, Bu."

Guru :"Untuk tugas sebaiknya dipisahkan. Jadi fokus penilaian tugasnya rapi." (058/Ns-04/L)

Siswa: (Menjawab serentak) "Iya, Bu."

\section{Konteks}

Tuturan tersebut merupakan tindak tutur direktif yang mengandung fungsi komunikatif menasihati. Pada tuturan tersebut, guru menganjurkan agar para siswa memisahkan antara buku tugas dengan buku cacatan. Tuturan menasihati pada tuturan tersebut juga dapat diketahui dengan adanya penanda lingual "sebaiknya" yang terdapat pada tuturan.

\section{Realisasi Fungsi Komunikatif Tindak Tutur Direktif}

Berdasarkan hasil penelitian keenam fungsi komunikatif tindak tutur direktif guru perempuan dalam pembelajaran bahasa Indonesia kelas XI direalisasikan secara langsung dan tidak langsung. Kelangsungan dan ketidaklangsungan tuturan ini didasarkan pada hubungan struktur dan maksud tuturan. Tindak tutur langsung adalah tindak tutur yang struktur tuturan dan fungsi komunikatifnya sama, sedangkan tindak tutur tidak langsung adalah tindak tutur yang struktur tuturan dan fungsi komunikatifnya tidak sama. Berikut ini disajikan data fungsi komunikatif tindak tutur direktif guru perempuan dalam pembelajaran bahasa Indonesia kelas XI yang direalisasikan dengan tindak tutur langsung (L), dan tidak langsung (TL), berikut penjelasannya.

\section{a. Tindak Tutur Direktif Meminta}

Berikut ini disajikan data yang termasuk tindak tutur direktif yang mengandung fungsi meminta secara langsung dan tidak langsung. 
a) Tindak Tutur Langsung

Guru : "Ibu minta untuk setiap baik itu keterangan maupun dialog nanti diberikan penomoran." (029/Mt-07/L)

Siswa: (Menjawab serentak) "Iya, Bu."

\section{Konteks}

Data di atas merupakan tindak tutur direktif meminta yang direalisasikan dengan tindak tutur langsung. Hal ini dapat diketahui karena stuktur tuturan dan fungsi komunikatifnya pun sama, yakni struktur imperatif dan fungsinya meminta.

\section{b) Tindak Tutur Tidak Langsung}

Guru : "Seandainya ada yang merasa kelompoknya tidak cocok, justru di sinilah kalian belajar untuk bisa bekerja sama dengan orang yang berbeda-beda karakter." (041/Mt-10/TL)

Siswa: (Para siswa terdiam)

\section{Konteks}

Data di atas merupakan tindak tutur direktif meminta yang direalisasikan dengan tindak tutur tidak langsung. Hal ini dapat diketahui karena struktur tuturan dan fungsinya tidak sama, yakni deklaratif dan meminta. Artinya, tuturan tersebut tidak hanya bermaksud memberitahukan saja. Akan tetapi, secara tidak langsung penutur (guru) meminta agar para siswa bisa menerima anggota kelompoknya masingmasing.

\section{b. Tindak Tutur Direktif Menanya}

Berikut ini disajikan data yang termasuk tindak tutur direktif yang mengandung fungsi menanya secara langsung dan tidak langsung.

\section{a) Tindak Tutur Langsung}

Ketika Guru sedang menjelaskan, kemudian datang siswa yang bernama Jodi dan langsung menyerahkan surat kepada guru).

Siswa : (Jodi menghampiri guru dan memberikan surat izin perlombaan)

Guru : "Mau lomba dimana?" (163/Ty-39/L)

Siswa : "Di STM, Bu."

Guru : "Oh, ya. Ibu doakan semoga menang."

Siswa : (Menjawab serentak) "Amin."

\section{Konteks}

Data di atas merupakan tuturan menanya yang direalisasikan dengan tindak tutur langsung karena struktur dan fungsi komunikatifnya pun sama, yakni struktur interogatif yang secara konvensional digunakan untuk menanyakan sesuatu dan maksudnya juga menanya sesuatu, yakni tempat pelaksanaan perlombaan. 
AKSARA Jurnal Bahasa dan Sastra

Vol. 18, No. 2, Hal. 100 - 112, Oktober 2017

http://jurnal.fkip.unila.ac.id/index.php/aksara

\section{b) Tindak Tutur Tidak Langsung}

Guru : "Yang Imam ini, Ibu pelajari sudah lima kali alpaya?"

(055/Ty-14/TL) (Sambil memandang ke semua siswa)

Siswa : (Salah satu siswa menjawab) "Kadang berangkatnya siang, Bu."

Guru :"Semoga yang lainnya tidak mengikuti jejak teman kalian yang sudah alpa."

Siswa : (Menjawab serentak) “Amin

\section{Konteks}

Data di atas merupakan tuturan yang direalisasikan dengan tindak tutur tidak langsung. Meskipun secara struktur dan maksud tuturannya sama, yakni interogatif dan maksudnya menanyakan, tetapi tuturan tersebut dituturkan oleh penutur tidak langsung ditujukan kepada mitra tutur namun melalui pelantara.

\section{c. Tindak Tutur Direktif Memerintah}

Berikut ini disajikan data yang termasuk tindak tutur direktif yang mengandung fungsi memerintah secara langsung dan tidak langsung.

a) Tindak Tutur Langsung

Guru : "Coba perhatikan sebentar ya, waktunya sudah habis."

(047/Pr-16/L)

(Sambil menunjuk jam dinding).

Siswa: (Langsung memerhatikan) "Iya, Bu."

\section{Konteks}

Data tersebut merupakan tindak tutur langsung karena penutur (guru) secara langsung mengungkapkan maksud tuturannya agar para siswa memerhatikan. Kemudian, jika dilihat dari realisasi tuturannya maka tuturan tersebut direalisasikan dengan tindak tutur langsung karena struktur dan maksud tuturan sama, yakni stuktur imperatif dan maksudnya memerintah.

\section{b) Tindak Tutur Tidak Langsung}

Guru: "Apa ada yang piket hari ini?" (057/Pr-17/TL)

(Sambil menunjuk ke papan tulis)

Siswa : (Siswa yang pikiet segera menghapus papan tulis)

\section{Konteks}

Data di atas merupakan tuturan yang direalisasikan dengan tindak tutur tidak langsung karena struktur dan maksudnya tidak sama, yakni struktur interogatif yang digunakan untuk memerintah. Hal ini pun dapat diketahui dengan melihat tindakan mitra tutur yang saat itu juga segera menghapus papan tulis. 
AKSARA Jurnal Bahasa dan Sastra

Vol. 18, No. 2, Hal. 100 - 112, Oktober 2017

http://jurnal.fkip.unila.ac.id/index.php/aksara

\section{d. Tindak Tutur Direktif Melarang}

Berikut ini disajikan data yang termasuk tindak tutur direktif yang mengandung fungsi melarang secara langsung dan tidak langsung.

a) Tindak Tutur Langsung

Guru: "Kalau satu temannya sudah selesai, langsung bergantian dengan temannya."

Siswa: "Sudah sepuluh menit."

Guru : "Jangan diganggu." (96/Lr-06/L)

Siswa: (Langsung terdiam dan kembali menghitung kecepatan membaca

Temannya)

\section{Konteks}

Data di atas merupakan tuturan direktif melarang yang direalisasikan dengan tindak tutur langsung karena struktur dan maksud tuturannya sama, yakni menginginkan agar siswa tidak mengganggu temannya yang sedang membaca.

\section{b) Tindak Tutur Tidak Langsung}

Guru : "Kalau kira-kira cermin masih lebih disukai daripada buku yaitu perlu introspeksi." (112/Lr-07/TL)

Siswa : (Segera meletakkan cermin dan kembali memperhatikan guru)

Guru : "Kalau kira-kira cerminnya itu menggangu konsentrasi, lain kali ibu ambil. Jadi sebagai pelajar semestinya kalian lebih mencintai buku daripada cermin."

Siswa : "Iya, Bu." (Sambil menganggukkan kepala)

\section{Konteks}

Data tersebut merupakan tindak tutur direktif melarang yang direalisasikan dengan tindak tutur tidak langsung karena struktur dan maksud tuturan tidak sama, yakni struktur deklaratif secara konvensional untuk menginformasikan, tetapi digunakan penutur (guru) untuk melarang agar mitra tutur (siswa tersebut) tidak menggunakan cermin ketika jam pelajaran berlangsung.

\section{e. Tindak Tutur Direktif Mengizinkan}

Berikut ini disajikan data yang termasuk tindak tutur direktif yang mengandung fungsi mengizinkan secara langsung dan tidak langsung.

\section{a) Tindak Tutur Langsung}

Guru: "Kita akan ke perpustakaan, silahkan kalian cari buku yang sesuai dengan minat kalian."

(161/Iz-20/L)

Siswa: (Menjawab serentak) "Iya, Bu." 


\section{Konteks}

Data di atas merupakan tindak tutur direktif mengizinkan yang direalisasikan dengan tindak tutur langsung karena struktur dan maksud tutura sama, yakni struktur imperatif dan maksudnya mengizinkan. Pada tuturan tersebut, penutur (guru) secara langsung memberikan kebebasan kepada para siswa untuk mencari buku yang akan mereka rangkum dengan kehendaknya masing-masing.

b) Tindak Tutur Tidak Langsung

Guru: "Penampil berikutnya siapa Husen?" (145/Iz-19/TL)

Siswa: (Husen) "Lulu."

Siswa : (Lulu segera maju)

\section{Konteks}

Data di atas merupakan tindak tutur direktif mengizinkan yang direalisasikan dengan tindak tutur tidak langsung karena struktur dan maksud tuturan tidak sama, yakni struktur interogatif yang secara konvensional digunakan untuk menanyakan sesuatu, tetapi tuturan di atas oleh penutur digunakan untuk mengizinkan. Hal ini dapat dilihat dari maksud penutur yang tidak hanya menanyakan saja, tetapi juga secara tidak langsung penutur (guru) telah memberikan kebebasan kepada siswa yang bernama Husen untuk memilih penampil berikutnya.

\section{f. Tindak Tutur Direktif Menasihati}

Berikut ini disajikan data yang termasuk tindak tutur direktif yang mengandung fungsi menasihati yang direalisasikan secara langsung dan tidak langsung.

a) Tindak Tutur Langsung

Siswa : "Bu, bukunya dikumpul."

Guru :"Iya bukunya dikumpul. Untuk notulennya belum selesai ibu koreksiya."

Siswa : "Tapi bukunya jadi satu, Bu."

Guru :"Untuk tugas sebaiknya dipisahkan. Jadi fokus penilaian tugasnya rapi." (058/Ns-04/L)

Siswa : (Menjawab serentak) "Iya, Bu."

\section{Konteks}

Data tersebut merupakan tindak tutur direktif menasihati yang direalisasikan dengan tindak tutur langsung karena struktur dan maksud tuturan sama, yakni struktur imperatif dan maksudnya menasihati. Tuturan ini langsung ditujukan kepada para siswa agar memisahkan antara buku tugas dengan buku catatan.

\section{b) Tindak Tutur Tidak Langsung}




\section{Guru: "Lain kali begini ya nak, untuk hari ini masih ibu beri toleransi, tapi lain kali buku itu penting. Jadi kalau kalian lupa tidak membawa buku, seharusnya ada usaha. Bagaimana caranya?" (075/Ns-07/TL)}

Siswa: (Menjawab serentak) "Pinjam."

\section{Konteks}

Data di atas merupakan tindak tutur direktif menasihati yang direalisasikan dengan tindak tutur tidak langsung karena struktur dan maksud tuturan tidak sama, yakni struktur interogatif dan maksudnya menasihati. Hal ini pun dapat dilihat dari maksud tuturannya yang tidak hanya menanyakan saja, tetapi juga secara tidak langsung menganjurkan agar siswa yang tidak membawa buku berusaha untuk meminjam buku.

\section{KESIMPULAN DAN SARAN}

\section{A. Kesimpulan}

Dari hasil penelitian ini, menunjukkan bahwa tindak tutur direktif guru perempuan berdasarkan fungsi komunikatifnya yang lebih dominan digunakan dalam pembelajaran di kelas adalah fungsi memerintah. Sedangkan tindak tutur direktif guru perempuan berdasarkan realisasi tuturannya yang lebih dominan digunakan dalam pembelajaran di kelas adalah tindak tutur langsung..

Hal ini memungkinkan karena ini dalam konteks pembelajaran yang tentu saja guru memilih lebih banyak kekuasaan untuk memerintah. Sedangkan jika dilihat secara teoretis bahwa guru perempuan cenderung memiliki gaya tutur kooperatif atau bersifat kerja sama dan lebih lembut yang identik dengan ketidaklangsungan karena ini dalam konteks pembelajaran yang cenderung formal sehingga memerlukan tuturan yang lugas atau mudah dipahami.

\section{B. Saran}

1. Bagi guru, hendaknya mampu memilih tuturan yang tepat pada saat berkomunikasi dengan siswa dalam proses pembelajaran.

2. Bagi para mahasiswa, khususnya para pembelajar bahasa Indonesia, hendaknya lebih meningkatkan pengetahuan mengenai bahasa perempuan dan wawasan ilmu Pragmatik, khususnya kajian tindak tutur direktif.

3. Bagi peneliti selanjutnya, hendaknya meneliti tindak tutur direktif guru lakilaki, dan bisa juga dilanjutkan kajian perbandingan antara tindak tutur direktif guru perempuan dan guru laki-laki, serta dapat dilakukan penelitian lanjutan berupa tindak tutur direktif bagi keluarga, misalnya tindak tutur direktif Ayah dan Ibu dan masyarakat, misalnya tindak tutur direktif pedangang perempuan dan laki-laki. 


\section{DAFTAR PUSTAKA}

Ibrahim, Syukur Abd. 1993. Kajian Tindak Tutur. Surabaya: Usaha Nasional. Moleong, Lexy J. 2012. Metode Penelitian Kualitatif. Bandung: PT Remaja Rosdakarya.

Rusminto, Nurlaksana Eko. 2015. Analisis Wacana: Sebuah Kajian Teoretis dan Praktis. Yogyakarta: Graha Ilmu.

Santoso, Anang. 2011. Bahasa Perempuan: Sebuah Potret Ideologi Perjuangan. Jakarta: Bumi Aksara.

Sumarsono. 2014. Sosiolinguistik. Yogyakarta: Pustaka Pelajar

Wijana, I Dewa Putu. 1996. Dasar-dasar Pragmatik. Surakarta: Yuma Pustaka. Yule, George. 2006. Pragmatik. Yogyakarta: Andi Offset. 